\title{
Climate variability during flowering and fruiting reduces fruit yield of ber (Ziziphus mauritiana) in Western Rajasthan
}

\author{
PR Meghwal, P Kumar \& D Singh
}

Journal of Agriculture and Ecology

ISSN: 2456-9410

Volume: 6

Journal of Agriculture and Ecology (2018) 6: 31-38 http://doi.org/10.53911/JAE.2018.6204

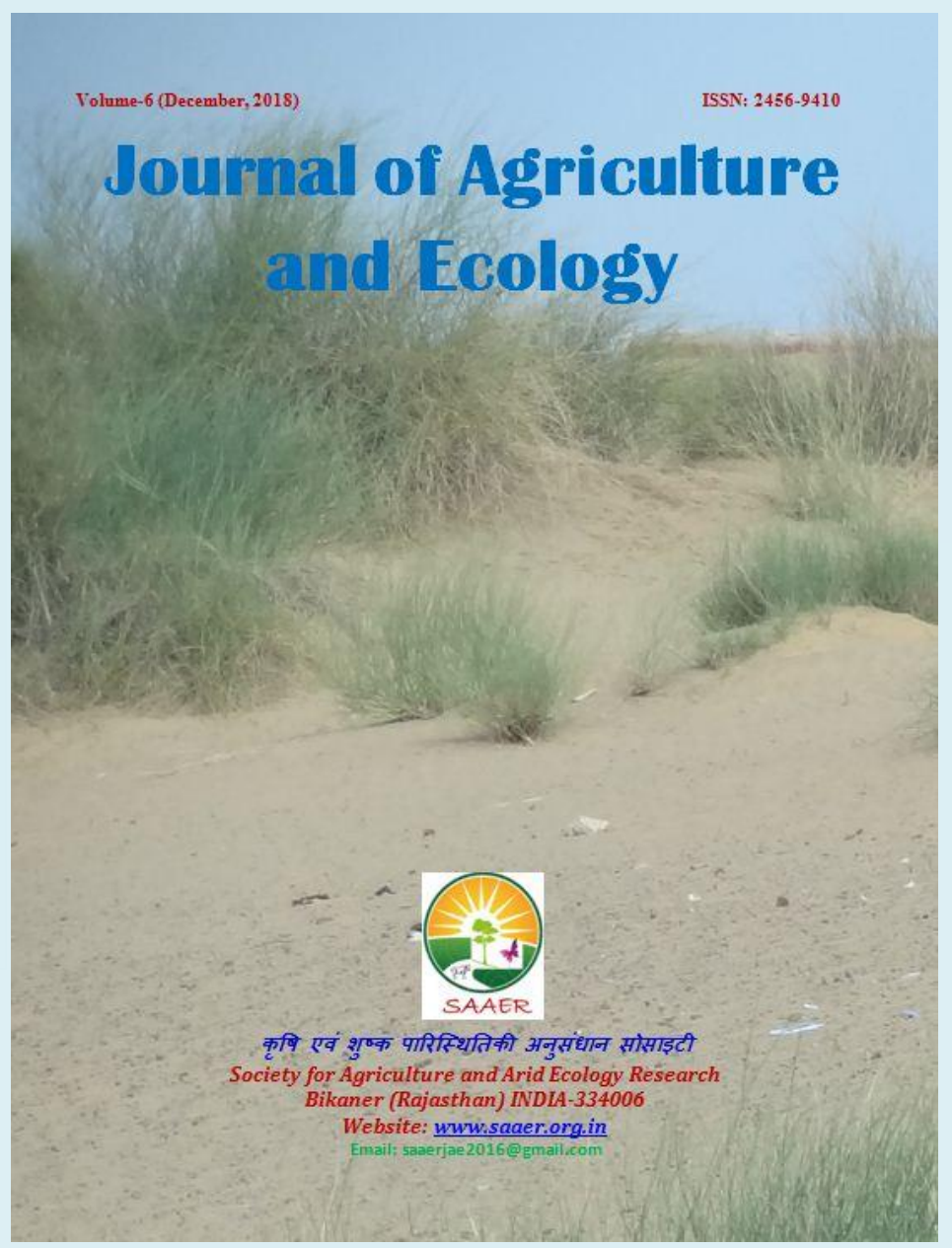


Climate variability during flowering and fruiting reduces fruit yield of ber (Ziziphus mauritiana) in Western Rajasthan

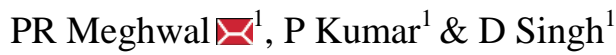 \\ ${ }^{I}$ ICAR-Central Arid Zone Research Institute, Jodhpur 342003, India \\ D Corresponding author: PR Meghwal,E-mail:prm20964@gmail.com
}

\section{Article Info}

Article history

Received: 30 July 2018

Accepted: 15 August 2018

Available online: 25

September 2018

Key Words: Climate variability, arid regions, Ziziphus mauritiana, flower drying, maximum temperature, relative humidity.

\begin{abstract}
The arid regions of western Rajasthan have multiple environmental adversities besides low and erratic rainfall. The region also faces frequent drought and often with failure of annual crops. Indian jujube or ber is perennial drought hardy multipurpose fruit species suitable for these areas which fits well in the integrated farming system. Recent years have witnessed climatic variability especially in post monsoon season usually with rise in temperature and decline in relative humidity. An insight into the post monsoon weather data from 2015-17 have revealed definite change in these parameters which led to decreased fruit set and ultimately reduction in total fruit yield. Early varieties like CAZRI Gola and Gola maintain higher yield even under climatic variable situation. Climate change being a global issue calls for immediate adaptive measures such as modification in microclimate and rescheduling the pruning to minimize the adverse impact of climatic variability.
\end{abstract}

Copyright (C2018 Meghwal et al., This is an open access article published under the terms of the Creative Commons Attribution License, which permits unrestricted use, distribution, and reproduction in any medium, provided the original work is properly cited.

Preferred citation: Meghwal PR, Kumar P \& Singh D. 2018. Climate variability during flowering and fruiting reduces fruit yield of ber (Ziziphus mauritiana) in Western Rajasthan. Journal of Agriculture and Ecology, 6: 31-38; http://doi.org/10.53911/JAE.2018.6204.

\section{Introduction}

The arid regions are characterized by scanty rainfall with erratic distribution and frequent drought which often cause complete or partial failure of annual crops. The light soils of arid zone are poor in fertility with low water holding capacity and high infiltration rate. The condition is further aggravated by intense solar radiation and high wind velocity which takes away most of the water from land plant surface through enhanced evapotranspiration. Under such situation, growing of drought hardy perennial multipurpose fruit crop like ber or Indian Jujube (Ziziphus mauritiana Lam.) can impart resilience to the fragile ecosystem besides nutritional supports to the masses. Indian jujube is an important fruit crop of tropical, subtropical and arid regions the world over. It is one the few fruit crops which can successfully be cultivated in arid subtropics with excellent fruit quality (Haldahr et al 
2016; Haldhar et al 2018). The fruits of Indian jujube are mostly used as table fruits but they can also be candied and dried. The fruits are even richer than apple in respect to protein, phosphorus, calcium and vitamin ' $\mathrm{C}$ ' content (Bal et al. 1978). Besides fruits, its leaves are also source of nutritious fodder especially for camels, sheep, goat and cattle. However, in recent decades, climate change/climatic variability has started affecting the production of ber especially at fruiting time in various ways in hot arid regions of India. Sometimes temperature or air humidity fluctuates around the average with very little impact on longterm average. World Meteorological Organization defines climate variability as "variations in the mean state and other statistics of the climate on all temporal and spatial scales beyond individual weather events." In simpler terms, variability is the range of climate compared to its average. The fluctuations comprising climate variability can influence patterns of rainfall, temperature and other variables on timescales anywhere from a few weeks to a few decades.

Climate projection studies indicate a general increase of temperature from $3-6^{\circ} \mathrm{C}$ with more warming in the northern parts than the southern parts of India (Lonergan 1988). Another study predicts $1-4^{\circ} \mathrm{C}$ rise in temperature by the year 2030(Kumar et al. 2002) and $2-4.8^{\circ} \mathrm{C}$ increase by 2080 through ensemble modelling based on Fifth Report of IPCC (Chaturvedi et al. 2012). The predicted climatic variability is being realized in post monsoon period in the form of increased temperature and lower relative humidity. Using the all India surface temperature during
1901-2000, the trend in the mean annual temperature over the India worked out showed warming trend in post monsoon season of $0.05^{\circ} \mathrm{C}$ (Kumar et al. 2002). All India mean annual temperature has shown significant warming trend of $0.05^{\circ} \mathrm{C}$ per decade during 1901-2003 (Kothawale et al. 2005) while, the recent period 1971-2003 has shown relatively accelerated warming of $0.22^{\circ} \mathrm{C}$ per decade which is largely due to unprecedented warming during the last decade. Moreover, the rise in temperature may not be evenly distributed between day and night and between different seasons (Rao et al. 2010). There is also a greater consensus now that in future, climate variability in India will increase leading to more frequent extreme weather events in the form of uncertain onset of monsoon and frequency and intensity of drought and flooding etc (Prabhjyot-Kaur \& Singh 2011).

Although, ber tree can withstand extreme high temperature even up to $48^{\circ} \mathrm{C}$ when in dormancy but temperature above $35^{\circ} \mathrm{C}$ affects adversely the flowering and fruit set (Pareek 2001) which takes place from September to November. Most plant process related to growth and yield are highly temperature dependent and there can be an optimum range for maximum yield. The optimum growth temperature corresponds to optimum temperature for photosynthesis and other metabolic reactions. The perennial crops are generally grown in a climate near to its optimum, a slight increase in temperature could reduce photosynthesis and shorten the growing period affecting the productivity (Dhillon 2011). In north western parts of 
India, ber trees enter in dormancy with leaf senescence and leaf fall during summer months (April-June). The trees evade adverse impact of high temperature and dry winds due to dormant season during this period. The new leaves emerge with the onset of monsoon with luxuriant vegetative growth due to favorable weather conditions. Recently ber orchards in western Rajasthan have been showing decreased fruit set and inconsistent yield due to climatic variability. However, under the influence of climatic variability mainly in terms of high temperature and low relative humidity during September-November affect flowering and fruit set adversely leading to decrease in fruit yield. Similar experiences have been shared by the ber growers of western Rajasthan with the senior author through personal letters and telephonic conversations. With this back ground, a small study was conducted on the effect of climatic variability on fruit yield of 22 cultivars of ber under rain fed condition from 2015-16 to 2017-18.

\section{Materials and Methods}

The study was conducted at CR Farm, ICAR-Central Arid Zone Research Institute, Jodhpur for three consecutive years (2015-17). The weather data on annual rainfall, relative humidity and temperature during most sensitive period i.e. from SeptemberNovember during the study period being regularly recorded at the institute were used. Thirty-five years old ber orchard of 22 cultivars laid out in Randomized Block Design with three replications having 15 plants per replication were studied for fruiting and yield. The plants were maintained under rainfed condition with uniform cultural practices. Since all the packages of practices including the inputs were same, the yield varies mainly due to annual rainfall and prevailing weather at flowering and fruiting. The fruit yield was recorded from three plants per replication from each variety during the fruiting season 2015-16 to 2017-18. The data were analyzed statistically.

\section{Results and Discussion}

The mean maximum temperature and minimum relative humidity during September to November for three years (2015-2017) are presented in Fig.1 and Fig.2. These two variables were selected as they have been reported in the literature to impede the process of pollination and may also affect the activity of pollinators. The mean maximum temperature during October, 2017 was $38.4^{\circ} \mathrm{C}$ as compared to $35-36^{\circ} \mathrm{C}$ in 2015 and 2016 . Similarly, the minimum relative humidity also showed a progressive decline during the month of October from 2015-2017 (Fig. 2). Similar changes in maximum temperature and minimum relative humidity during the same period on decadal basis (1991-2010) at Jodhpur (Rajasthan) has been reported (Roy et al. 2012). The mean fruit yield data of 22 varieties of ber are given in Table 1. Significant differences in fruit yield were observed in different varieties during a particular year which is quite obvious. Since all the varieties were grown under uniform cultural practices, the yield varied due to genotypic and environmental factors. The fruit yield also varied in different years which could be mainly attributed to variable annual rainfall and atmospheric conditions at the time 
of flowering and fruit set (September- November).

Table 1. Averages monthly temperature and relative humidity $(\mathrm{RH})$ during fruiting season of ber during 2015-17

\begin{tabular}{|c|c|c|c|c|c|c|c|}
\hline \multirow[t]{2}{*}{ Year/month } & \multicolumn{2}{|c|}{$\begin{array}{l}\text { Mean Temperature } \\
{ }^{0} \mathrm{C}\end{array}$} & \multicolumn{2}{|c|}{ Mean RH (\%) } & \multirow{2}{*}{$\begin{array}{l}\text { Frequency } \\
\text { of Min RH } \\
\text { below } \\
30 \% \text { (days) }\end{array}$} & \multirow{2}{*}{$\begin{array}{l}\text { Temp } \\
\text { Range } \\
{ }^{0} \mathrm{C}\end{array}$} & \multirow{2}{*}{$\begin{array}{c}\text { Frequency } \\
\text { of Max } \\
\text { temp above } \\
35^{\circ} \mathrm{C} \text { (days) }\end{array}$} \\
\hline & $\operatorname{Max}$ & Min & Max & Min & & & \\
\hline \multicolumn{8}{|l|}{2015} \\
\hline September & 36.4 & 25.35 & 68.6 & 36.4 & 11 & $22.3-40.4$ & 23 \\
\hline October & 36.85 & 20.89 & 59.54 & 59.51 & 0 & $17.5-39.5$ & 27 \\
\hline $\begin{array}{l}\text { November } \\
2016\end{array}$ & 31.59 & 17.63 & 56.4 & 24.33 & 25 & $13.6-35.1$ & 1 \\
\hline September & 35.73 & 24.79 & 77.1 & 42.5 & 3 & $17-40.2$ & 17 \\
\hline October & 35.07 & 21.45 & 73.70 & 33.17 & 16 & $17-38$ & 15 \\
\hline $\begin{array}{l}\text { November } \\
2017\end{array}$ & 32.01 & 12.94 & 76.7 & 20.43 & 30 & $10.5-34.4$ & 0 \\
\hline September & 35.61 & 25.33 & 76.76 & 43.13 & 6 & $23.6-39.8$ & 23 \\
\hline October & 38.40 & 20.25 & 55.16 & 14.45 & 31 & $16.4-39.8$ & 31 \\
\hline November & 31.01 & 15.19 & 58.16 & 21.1 & 25 & $10.6-36.1$ & 4 \\
\hline
\end{tabular}

Fig.1 Mean maximum temperature during flowering/ fruiting (Sep.-Nov.) in ber

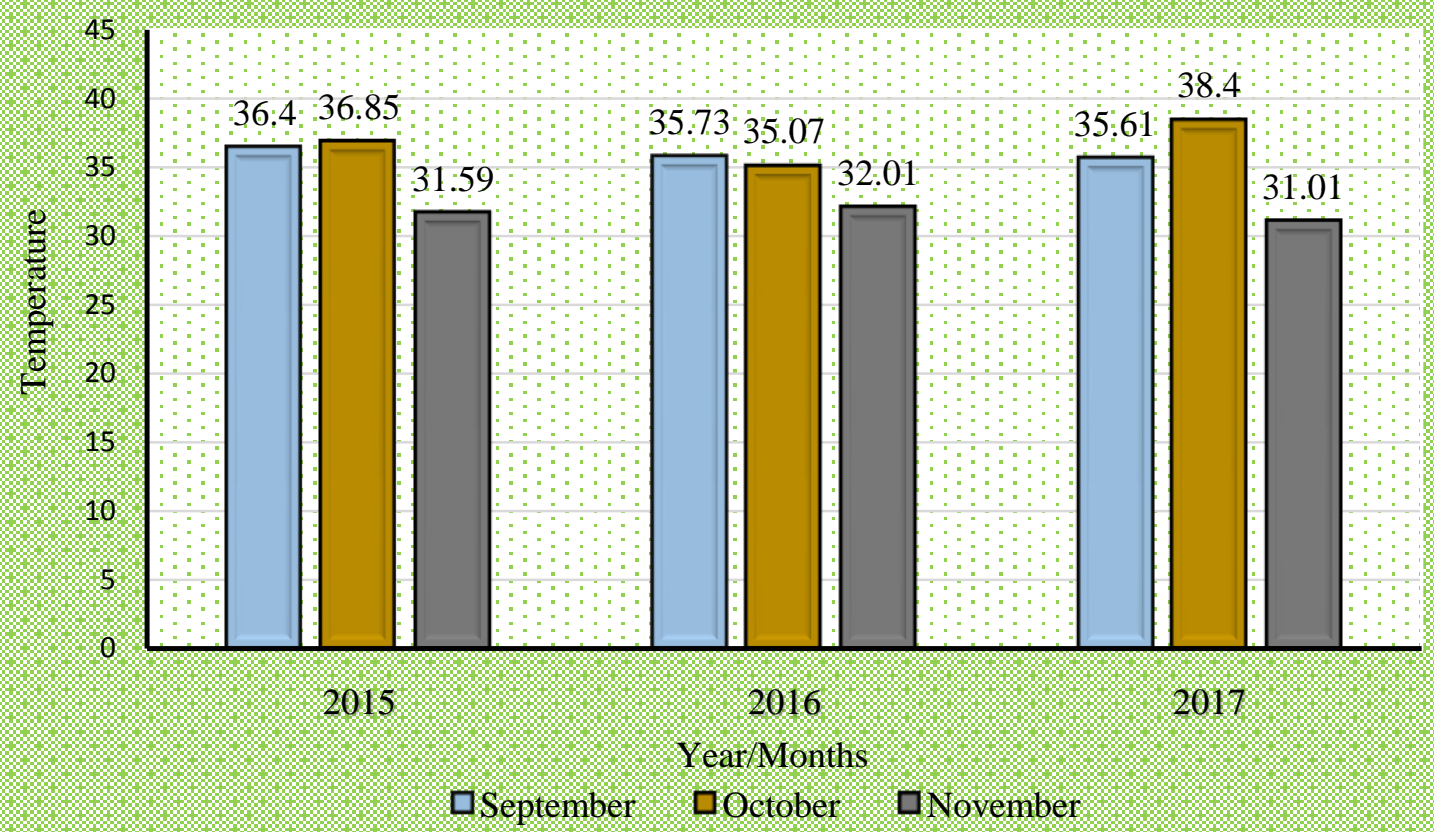


Fig.2 Mean minimum relative humidity during flowering/ fruiting (Sep.-Nov.) in ber

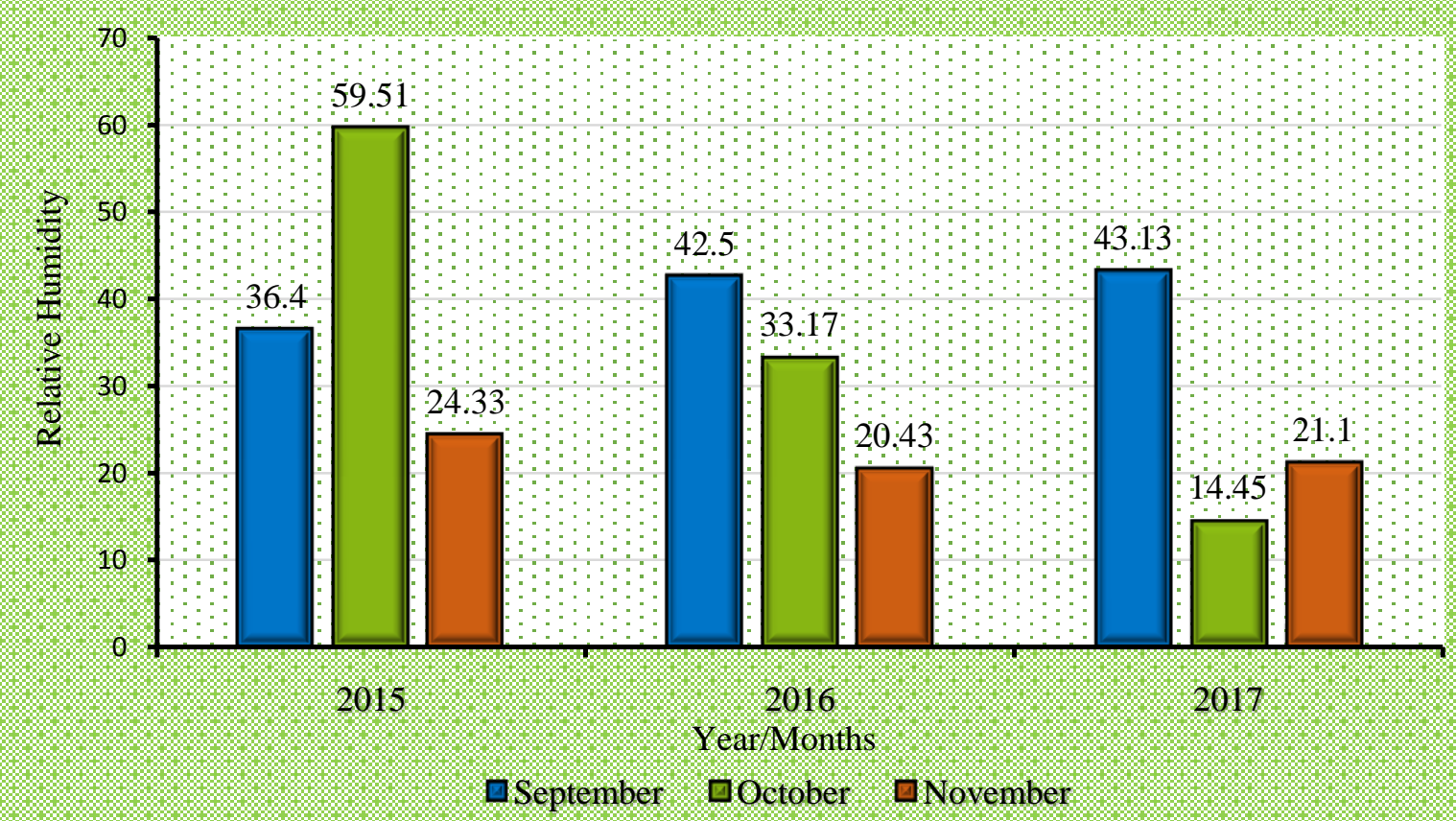

The flowering and fruit setting in ber takes place from September to November and the per cent fruit set and its retention is determined by the temperature and relative humidity condition prevailing during this period. The fruit set in ber is adversely affected if the maximum temperature exceeds $35^{\circ} \mathrm{C}$ (Pareek 2001, Samadia \& Haldhar 2017). The impact of higher maximum temperature is further multiplied if it is accompanied by minimum relative humidity lesser than $30 \%$. The adverse impact of temperature higher than $35^{\circ} \mathrm{C}$ and relative humidity lower than $30 \%$ further depend upon its duration. This type of impact brought about by temperature higher than optimum and lesser relative humidity is further aggravated in the rainfed orchard which is already under water stress cause excessive transpiration and dehydration injuries to flower panicles. The frequency of maximum temperature above $35^{\circ} \mathrm{C}$ and minimum relative humidity below $30 \%$ in days has shown increasing trend from the year 2015 to 2017 during all the three months (Table1). The cumulative effect of frequency and degree of maximum temperature and lower relative humidity might led to lower fruit yield across all the varieties in 2017-18 as compared to previous two years. The mean fruit yield of 22 varieties (35.64 kg plant ${ }^{-1}$ ) during 2015-16 was higher than $30.28 \mathrm{~kg}$ plant $^{-1}$ recorded in 2017-18 despite higher seasonal rainfall during 2017 (Table 2). The reduction in fruit yield may also be attributed to dehydration of flowers due to rise in day temperature during October month (Fig. 3), lesser fruit set and more premature fruit drop. This can be substantiated by the hypothesis that the rise in temperature by $1-2^{0} \mathrm{C}$ during flowering and 
fruit set adversely affect the potential of subtropical fruits (Dhillon, 4). The highest mean fruit yield across different rainfall years was recorded by variety CAZRI Gola $(71.50$ $\mathrm{kg}$ plant $\left.^{-1}\right)$ followed by Gola (51.12 kg plant $\left.{ }^{-1}\right)$ and the yield of these varieties was significantly higher over other varieties which

Table 2. Fruit yield (kg per plant) of different varieties of ber under rainfed conditions

\begin{tabular}{|c|c|c|c|c|}
\hline Year & $2015-16$ & 2016-17 & $2017-18$ & Mean \\
\hline Seasonal rainfall & 324.9 & 572.2 & 466.1 & \\
\hline \multicolumn{5}{|l|}{ Ber varieties } \\
\hline Tikadi & 33.87 & 35.33 & 27.83 & 32.34 \\
\hline Elaichi & 28.37 & 29.10 & 28.33 & 28.60 \\
\hline Jogiya & 28.83 & 30.67 & 16.17 & 25.22 \\
\hline Gola & 51.83 & 55.03 & 46.50 & 51.12 \\
\hline Umran & 40.17 & 42.17 & 35.50 & 39.28 \\
\hline Dandan & 34.60 & 37.03 & 18.67 & 30.10 \\
\hline Kali & 42.07 & 43.90 & 31.67 & 39.21 \\
\hline Sanaur-5 & 31.77 & 34.00 & 27.17 & 30.98 \\
\hline $\mathrm{Seb}$ & 30.27 & 31.87 & 25.67 & 29.27 \\
\hline Thornless & 37.17 & 39.13 & 31.6 & 35.97 \\
\hline Meharwali & 36.07 & 38.97 & 27.33 & 34.12 \\
\hline Chhuhara & 28.33 & 30.03 & 22.17 & 26.84 \\
\hline Kaithli & 34.93 & 37.97 & 29.50 & 34.13 \\
\hline Aliganj & 26.10 & 27.53 & 25.67 & 26.43 \\
\hline B. Pebandi & 27.63 & 28.47 & 23.30 & 26.47 \\
\hline B.Kadaka & 34.70 & 36.43 & 34.33 & 35.15 \\
\hline Katha & 33.27 & 34.87 & 32.23 & 33.46 \\
\hline ZG-3 & 30.60 & 32.10 & 27.43 & 30.04 \\
\hline Mundia & 34.23 & 36.70 & 32.20 & 34.38 \\
\hline Bagwadi & 35.27 & 37.50 & 27.20 & 33.32 \\
\hline Rashmi & 27.33 & 28.63 & 24.80 & 26.92 \\
\hline CAZRI Gola & 76.67 & 78.77 & 71.07 & 75.50 \\
\hline Mean & 35.64 & 37.55 & 30.28 & 34.49 \\
\hline $\mathrm{SEm} \pm$ & 2.40 & 2.54 & 1.77 & \\
\hline C.D. $(p=0.05)$ & 6.85 & 7.25 & 5.05 & \\
\hline
\end{tabular}

may be attributed to their early maturity nature. The early varieties complete fruit maturity before the soil moisture starts receding after the monsoon season and less affected by reduced availability of the

moisture in the root zone (Fig. 3). 
Fig. 3 Flower drying in ber due to high temperature during October

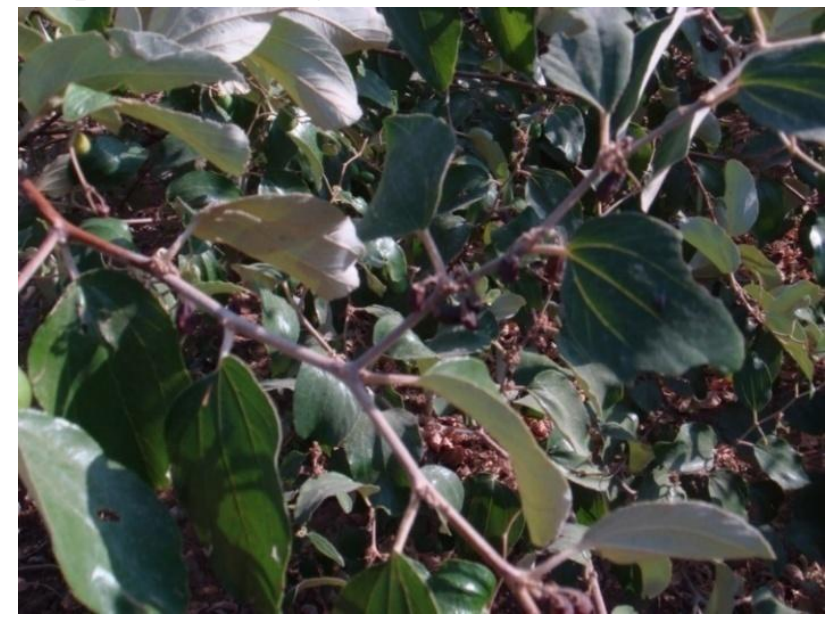

The trends of climatic variability during flowering and fruit setting of ber is being confirmed in recent decades in arid regions. This calls for certain mitigation measures to sustain the productivity of ber fruits. The possible measures to alleviate this problem could be microclimatic modification and delay in pruning schedules. Microclimatic modification can be created by boundary plantation and frequent light irrigation during flowering and fruiting period. Pruning during second fortnight of June than normal time during middle of May month may shift flowering and fruit setting towards second half of October to beginning of November when temperature and relative humidity condition are relatively more favourable for fruit set. The studies on delayed pruning of ber variety Gola has resulted in higher fruit yield at Jodhpur (Anonymous 2011-12)

\section{Acknowledgement}

The authors are grateful to the director ICAR-Central Arid Zone Research Institute,
Jodhpur for providing facilities and encouragement for conducting this research.

\section{References}

Anonymous. 2011-12. Annual Report. Central Arid Zone Research Institute, Jodhpur, Rajasthan, India, pp. 51.

Bal JS, Singh P \& Mann SS. 1978. Changes in total yellow pigments, protein and total carbohydrates during ripening of ber fruits. Progressive Horticulture, 10 (1), 73-75.

Chaturvedi RK, Joshi J, Jayaraman M, Bala G \& Ravindranath NH. 2012. Multimodal climate change projection for India under representative concentration pathways. Current Science, 103 (7):112.

Dhillon WS. 2011. Climate change and horticulture. In: Impact of Climate Change on Fruit Crops, Dhillon, W.S. and Aulakh, P.S. (Eds.), Narendra Publishing House, New Delhi, pp.177184.

Haldhar SM, Bhargava R, Krishna H, Berwal MK \& Saroj PL. 2018. Bottom-up effects of different host plant resistance cultivars on ber (Ziziphus mauritiana)fruit fly (Carpomyia vesuviana) interactions. Crop Protection, 106: 117124.

Haldhar SM, Deshwal HL, Jat GC, Berwal MK \& Singh D. 2016. Pest scenario of ber (Ziziphus mauritianaLam.) in arid regions of Rajasthan: a review. Journal of Agriculture and Ecology, 1: 10-21.

Kothawale DR \& Rupa Kumar K. 2005. Geophysics Research Letters, 32: L18714 doi:10.1029/2005GL023528. 
Lonergan S. 1998. Climate warming and India. In: Measuring the Impacts of Climate Change on Indian Agriculture, Dinar, A., Mendelsontin, R., Evenson, R. (Eds.), World Bank Technical Report No. 402. Washington DC, USA.

Pareek OP. 2001. Ber, International Centre for Underutilized Crops, Southampton, UK, pp. 292.

Prabhjyot-Kaur \& Singh H. 2011. Climate variability trend analysis over the past three decades. In: Impact of climate change on fruit crops, Dhillon, W.S. and Aulakh, P.S. (Eds.), Narendra Publishing House, New Delhi, pp.167-176.

Rao Srinivasa NK, Laxman RH \& Bhatt RM. 2010. Impact of climate change on vegetable crops. In: Challenges of Climate Change in Indian Horticulture, Singh, H. P., Singh, J. P. and Lal, S. S. (Eds.), Westville Publishing House, New Delhi, pp. 113-123.
Roy MM, Meghwal PR, Kumar S \& Roy S. 2012. Horticulture in arid region of India-impact and adaptive strategies in relation to climate change. In: Adaptation and Mitigation Strategies for Climate Resilient Horticulture, Shivashankara, K. S., Patil, P. Selvakumar, G. and Sridhar. V. (Eds.), IIHR, Bangalore, pp. 282-284.

Rupa Kumar K, Krishna Kumar K, Pant GB \& Srinivasan G. 2002. Background paper prepared by FICCI. International Conference on Science and Technology capacity building for climate change, Oct. 20-22, New Delhi.

Samadia DK \& Haldhar SM. 2017. Breeding strategies and scope of improvement in arid zone fruit cropplants under abiotic stressed agroclimate: an analysis. Journal of Agriculture and Ecology, 4: 1-13. 